\title{
PENGARUH PENAMBAHAN TEPUNG TAPIOKA DALAM PEMBUATAN BISKUIT BERBAHAN BAKU TEPUNG UBI BANGGAI (Dioscorea alata L.)
}

\author{
Effects of Addition of Tapioca Flour in Biscuits Made from Banggai Yam Flour \\ (Dioscorea alata L.)
}

\author{
Selvi Sovyani ${ }^{1 *}$, Jenny E. A. Kandou ${ }^{2)}$, Maria F. Sumual ${ }^{2)}$ \\ ${ }^{1)}$ Mahasiswa Program Studi Teknologi Pangan \\ ${ }^{2)}$ Dosen Program Studi Teknologi Pangan \\ Jurusan Teknologi Pertanian Fakultas Pertanian Universitas Sam Ratulangi \\ Jl. Kampus UNSRAT Manado, 95115. \\ *Email: sovyaniselvi@gmail.com
}

\begin{abstract}
The purpose of this study was to determine the proportion of tapioca flour that needs to be added in the manufacture of biscuits made from Banggai yam flour, based on sensory and chemical properties. This research used a Completely Randomized Design (CRD) with the addition of tapioca flour at four levels as treatments, i.e. A: 0\%; B: 5\%; C: 10\%; D: 15\%, which was triplicated. The parameters observed were organoleptic testing for the degree of preference for taste, aroma, color and texture. The chemical composition of the biscuits was analyzed and the energy value was calculated. Overall, the level of preference given by the panelists on the Banggai yam biscuits without the addition of tapioca flour was 3.68 (like) out of 5 as the highest value. It can be concluded that tapioca flour does not need to be added in making Banggai yam biscuits. Banggai yam biscuits have a hardness of $1.93 \mathrm{~mm} / \mathrm{g} / \mathrm{sec}$. and energy value of $422.62 \mathrm{kkal}$, with the composition of $3.98 \%$ moisture, $8.13 \%$ protein, $11.10 \%$ fat, $3.68 \%$ ash, $72.55 \%$ carbohydrates, and $0.56 \%$. crude fiber.
\end{abstract}

Keywords: Banggai yam, tapioca flour, biscuits

\section{PENDAHULUAN}

Ubi Banggai (Dioscorea alata L.) merupakan tanaman pangan lokal masyarakat Kabupaten Banggai Provinsi Sulawesi Tengah. Ubi ini yang memiliki tiga warna berbeda yaitu putih, kuning dan ungu (Yusuf, 2015), dan juga memiliki rasa netral karena mengandung kadar gula yang rendah (Rostiawati, 1990).

Ubi Banggai mempunyai potensi yang cukup besar untuk ditingkatkan produksinya, karena dapat diproses menjadi berbagai makanan yang mampu mendorong pengembangan agroindustri dan penganekaragaman pangan, seperti produk inovasi yaitu pada pembuatan mie, tepung komposit, roti, dan biskuit dapat dikembangkan dari bahan baku ubi Banggai. (Rahardjo dkk., 2016)

Biskuit merupakan salah satu produk olahan pangan yang berbahan dasar tepung terigu, dan diperoleh melalui memanggang adonan dengan penambahan bahan makanan pendukung lainnya, dan 
menjadi makanan praktis karena dapat dimakan kapan saja serta memiliki daya simpan yang relatif lama (Wijaya, 2010). Kerenyahan biskuit dapat ditingkatkan dengan cara menambahkan sumber pati seperti tepung tapioka.

Tapioka merupakan pati yang diekstrak dari singkong. Tapioka memiliki kadar amilopektin yang tinggi, sehingga produk yang dibuat dengan tepung tapioka cenderung memiliki tekstur yang renyah, bersifat larut dalam air biasanya digunakan sebagai bahan pengisi dan pengikat yang menghasilkan tekstur yang plastis, dan kompak pada industri makanan seperti pada pembuatan dodol (Lestari, 2013).

Tujuan penelitian ini adalah untuk menentukan proporsi tepung tapioka yang perlu ditambahkan dalam pembuatan biskuit berbahan baku ubi Banggai dilihat dari sifat sensoris serta sifat kimia.

\section{METODE PENELITIAN}

\section{Waktu dan Tempat}

Penelitian ini telah dilakukan di Laboratorium Ilmu Pangan Jurusan Teknologi Pertanian Fakultas Pertanian Universitas Sam Ratulangi Manado dan Balai Riset dan Standarisasi Industri Manado.

\section{Alat dan Bahan}

Alat yang digunakan adalah ayakan 80 mesh, oven konveksi, tanur, alat kjeldahl, dan penetrometer Prescision Scientific. Bahan baku ubi Banggai putih, dan tepung tapioka.

\section{Rancangan Penelitian}

Penelitian ini menggunakan Rancangan Acak Lengkap (RAL) dengan 4 perlakuan dan 3 kali pengulangan:

A: Tanpa Penambahan Tepung Tapioka

B: Penambahan 5\% Tepung Tapioka

C: Penambahan 10\% Tepung Tapioka

D: Penambahan 15\% Tepung Tapioka

\section{Prosedur Penelitian \\ Pembuatan Tepung Ubi Banggai (Ramadhani, 2016) \\ Ubi Banggai terlebih dahulu dikupas kulitnya, kemudian dicuci dengan airbersih mengalir, selanjutnya diiris tipis kemudian dikeringkan dibawah sinar matahari selama tiga hari. Irisan ubi kering dihaluskan dan diayak menggunakan ayakan.}

Pembuatan Biskuit (Sayangbati, 2012)

Pada setiap $100 \mathrm{~g}$ tepung ubi Banggai ditambahkan tepung tapioka sesuai perlakuan. Kemudian tambahkan gula $30 \mathrm{~g}$, baking powder $1 \mathrm{~g}$, telur 1 butir, garam $2 \mathrm{~g}$, dan margarin $15 \mathrm{~g}$, diaduk hingga adonan menjadi homegen. Adonan lalu dicetak menggunakan cetakan biskuit. Setelah itu dipanggang dalam oven pada suhu $150^{\circ} \mathrm{C}$ selama 20 menit.

\section{Parameter pengujian}

Uji Organoleptik Tingkat Kesukaan (Rahayu. 2001)

Uji organoleptik dilakukan untuk mengetahui tingkat kesukaan atau penerimaan panelis terhadap produk biskuit. Panelis terdiri dari 20 orang dimana setiap panelis diminta memberikan penilaian secara pribadi terhadap sampel yang disajikan. Parameter yang diuji yaitu rasa, warna, aroma, dan tekstur dengan menggunakan skala hedonik pada 5 kriteria sebagai berikut $: 1$. Sangat tidak suka 2. Tidak suka 3. Netral 4. Suka 5. Sangat suka.

\section{Analisis Komposisi Kimia}

Komposisi kimia biskuit ubi banggai dianalisis menggunakan metode analisis proksimat terhadap kadar air, (Sudarmadji dkk., 1997), protein, lemak, abu, serat kasar (SNI 01-2891-1992). Perhitungan kadar karbohidrat menggunakan metode perhitungan bydifference sedangkan nilai kalori dihitung sebagai total energi lemak, protein, dan karbohidrat (Kkal). 
Uji Kekerasan (Metode penetrometer)

Penetrometer diletakkan pada tempat yang datar kemudian jarum dipasang, dan ditambah pemberat $50 \mathrm{~g}$. Kemudian sampel biskuit diletakkan pada dasar penetrometer sampai permukaan sampel bersinggungan dengan jarum. Selanjutnya tekan tuas (lever) penetrometer selama 10 detik. Penusukkan dilakukan sebanyak 3 kali pada tiga tempat, kemudian dibaca skala pada alat yang menunjukkan kedalaman penetrasi jarum kedalama sampel. Kekerasan biskuit dinyatakan dalam $\mathrm{mm} / \mathrm{g} /$ det. Prinsipnya semakin kecil nilai yang didapatkan maka tingkat kekerasan semakin besar.

\section{HASIL DAN PEMBAHASAN}

\section{Tingkat kesukaan terhadap rasa}

Hasil uji tingkat kesukaan panelis terhadap rasa pada biskuit ubi Banggai dengan penambahan tepung tapioka diperoleh dari nilai rata-rata berkisar 3,43,7 yaitu netral sampai suka, dapat dilihat pada tabel 1 .
Nilai tingkat kesukaan tertinggi terdapat pada perlakuan A (tanpa penambahan tepung tapioka) dengan nilai 3,7 sedangkan nilai terendah pada perlakuan B (penambahan 5\% tepung tapioka) dengan nilai 3,4. Hasil analisis sidik ragam rasa biskuit ubi Banggai menunjukan tidak terdapat pengaruh nyata dari penambahan tepung tapioka. Dari hasil yang didapat panelis lebih menyukai biskuit dengan perlakuan A (tanpa penambahan tepung tapioka) hal ini disebabkan biskuit perlakuan ini mempunyai rasa manis dan masih mempunyai rasa yang didominasi ubi Banggai. Rasa adalah persepsi dari indera pengecapan yang meliputi rasa asin, manis, asam dan pahit yang diakibatkan oleh bahan yang terlarut dalam mulut. Rasa merupakan faktor penting dalam menentukan keputusan bagi konsumen untuk menerima atau menolak suatu makanan (Meilgaard dkk., 1999).

Persentase yang menunjukan variasi respons panelis terhadap rasa biskuit ubi Banggai dapat dilihat pada tabel 2.

Tabel 1. Nilai rata-rata tingkat kesukaan terhadap rasa biskuit

\begin{tabular}{lcc}
\hline \multicolumn{1}{c}{ Perlakuan } & Rata-rata & \\
\hline A Tanpa Penambahan Tepung Tapioka & 3,7 & Suka \\
B Penambahan 5\% Tepung Tapioka & 3,4 & Netral \\
C Penambahan 10\% Tepung Tapioka & 3,6 & Suka \\
D Penambahan 15\% Tepung Tapioka & 3,5 & Suka \\
\hline
\end{tabular}

Tabel 2. Persentase tingkat kesukaan panelis terhadap rasa biskuit

\begin{tabular}{lccccc}
\hline & \multicolumn{4}{c}{ Persentase (\%) } \\
\cline { 2 - 6 } Perlakuan & $\begin{array}{c}\text { Sangat } \\
\text { tidak } \\
\text { Suka }\end{array}$ & $\begin{array}{c}\text { Tidak } \\
\text { suka }\end{array}$ & Netral & Suka & $\begin{array}{c}\text { Sangat } \\
\text { Suka }\end{array}$ \\
\hline A Tanpa Penambahan Tepung Tapioka & 0 & 20 & 15 & 45 & 20 \\
B Penambahan 5\% Tepung Tapioka & 0 & 20 & 40 & 35 & 5 \\
C Penambahan 10\% Tepung Tapioka & 0 & 15 & 30 & 35 & 20 \\
D Penambahan 15\% Tepung Tapioka & 0 & 25 & 35 & 35 & 5 \\
\hline
\end{tabular}


Hasil analisis varians dari variabel panelis menunjukkan pengaruh panelis tidak berbeda dengan nilai rata-rata tingkat kesukaan panelis terhadap rasa biskuit. Nilai kriteria suka dan sangat suka bervariasi berkisar 40\%-65\% dari total panelis. Persentase tertinggi diperoleh pada perlakuan A (tanpa penambahan tepung tapioka) pada kriteria suka dan sangat suka sebanyak $65 \%$ panelis

\section{Tingkat kesukaan terhadap aroma}

Hasil uji tingkat kesukaan panelis terhadap aroma pada biskuit ubi Banggai dengan penambahan tepung tapioka diperoleh dari nilai rata-rata berkisar 3,63,9 yaitu suka, dapat dilihat pada tabel 3 .

Nilai tingkat kesukaan tertinggi terdapat pada perlakuan A (tanpa penambahan tepung tapioka) dengan nilai 3,9, sedangkan nilai terendah pada perlakuan C (penambahan 10\% tepung tapioka) dengan nilai 3,6 pada kriteria suka. Hasil analisis sidik ragam aroma biskuit ubi Banggai menunjukan tidak terdapat pengaruh nyata dari penambahan tepung tapioka. Aroma adalah bau yang ditimbulkan oleh rangsangan kimia yang tercium oleh syaraf-syaraf yang berada dalam rongga hidung ketika makanan masuk ke dalam mulut (Winarno, 2004). Aroma yang baik akan meningkatkan tingkat kesukaan panelis terhadap suatu produk pangan.

Berdasarkan persentase yang menunjukan variasi respons panelis terhadap rasa biskuit ubi Banggai dapat dilihat pada tabel 3. Hasil analisis varians dari variabel panelis menunjukkan pengaruh panelis tidak berbeda dengan nilai rata-rata tingkat kesukaan panelis terhadap aroma biskuit. Nilai kriteria suka dan sangat suka bervariasi berkisar 5575\% dari total panelis. Nilai tertinggi diperoleh pada perlakuan B (penambahan $5 \%$ tepung tapioka) dengan persentase tertinggi pada kriteria suka dan sangat suka sebanyak $75 \%$ panelis.

Tabel 3. Nilai rata-rata tingkat kesukaan panelis terhadap aroma biskuit

\begin{tabular}{lcc}
\hline \multicolumn{1}{c}{ Perlakuan } & Rata-rata & \\
\hline A Tanpa Penambahan Tepung Tapioka & 3,9 & Suka \\
B Penambahan 5\% Tepung Tapioka & 3,8 & Suka \\
C Penambahan 10\% Tepung Tapioka & 3,6 & Suka \\
D Penambahan 15\% Tepung Tapioka & 3,8 & Suka \\
\hline
\end{tabular}

Tabel 4. Persentase Tingkat Kesukaan Panelis Terhadap Aroma Biskuit.

\begin{tabular}{lccccc}
\hline \multirow{2}{*}{ Perlakuan } & \multicolumn{5}{c}{ Persentase (\%) } \\
\cline { 2 - 6 } & $\begin{array}{c}\text { Sangat } \\
\text { tidak } \\
\text { Suka }\end{array}$ & $\begin{array}{c}\text { Tidak } \\
\text { Suka }\end{array}$ & Netral & Suka & $\begin{array}{c}\text { Sangat } \\
\text { Suka }\end{array}$ \\
\hline A Tanpa Penambahan Tepung Tapioka & 0 & 15 & 15 & 55 & 15 \\
B Penambahan 5\% Tepung Tapioka & 0 & 0 & 25 & 65 & 10 \\
C Penambahan 10\% Tepung Tapioka & 0 & 10 & 30 & 50 & 5 \\
D Penambahan 15\% Tepung Tapioka & 0 & 5 & 25 & 60 & 10 \\
\hline
\end{tabular}




\section{Tingkat kesukaan terhadap warna}

Hasil pengamatan tingkat kesukaan panelis terhadap warna pada biskuit ubi Banggai dengan penambahan tepung tapioka diperoleh dari nilai rata-rata berkisar 3,2-3,6 yaitu tidak suka sampai sangat suka, dapat dilihat pada tabel 5 .

Berdasarkan penelitian yang memperoleh nilai tertinggi yaitu pada perlakuan A (tanpa penambahan tepung tapioka) dan perlakuan B (penambahan $5 \%$ tepung tapioka) dengan nilai 3,6 pada kriteria suka, sedangkan nilai terendah pada perlakuan D (penambahan 15\% tepung tapioka) dengan nilai 3,2 pada kriteria netral. Hasil analisis sidik ragam warna biskuit ubi Banggai menunjukan tidak terdapat pengaruh nyata dari penambahan tepung tapioka. Dari hasil yang diperoleh, panelis lebih menyukai biskuit dengan perlakuan A (tanpa penambahan tepung tapiuoka) dan perlakuan B (penambahan 5\% tepung tapioka). Panelis lebih menyukai biskuit dengan warna yang lebih cerah dari pada biskuit dengan warna gelap.

Perubahan warna terjadi karena adanya reaksi pencoklatan non enzimatis selama proses pemanggangan menggunakan suhu tinggi dalam waktu yang lama (Cauvin, 2003).

Persentase yang menunjukan variasi respons panelis terhadap warna biskuit ubi Banggai dapat dilihat pada tabel 6. Hasil analisis varians dari variabel panelis menunjukkan pengaruh panelis tidak berbeda dengan nilai rata-rata tingkat kesukaan panelis terhadap warna biskuit. Nilai kriteria suka dan sangat suka bervariasi berkisar 25-55\% dari total panelis. Nilai tertinggi diperoleh pada perlakuan A (tanpa penambahan tepung tapioka) dan perlakuan B (penambahan $5 \%$ tepung tapioka) dengan persentase tertinggi pada kriteria suka dan sangat suka sebanyak $65 \%$ panelis.

Tabel 5. Nilai rata-rata tingkat kesukaan panelis terhadap warna biskuit

\begin{tabular}{lcc}
\hline \multicolumn{1}{c}{ Perlakuan } & Rata-rata & \\
\hline A Tanpa Penambahan Tepung Tapioka & 3,6 & Suka \\
B Penambahan 5\% Tepung Tapioka & 3,6 & Suka \\
C Penambahan 10\% Tepung Tapioka & 3,4 & Netral \\
D Penambaha 15\% Tepung Tapioka & 3,2 & Netral \\
\hline
\end{tabular}

Tabel 6. Persentase tingkat kesukaan panelis terhadap warna

\begin{tabular}{lccccc}
\hline & \multicolumn{5}{c}{ Persentase (\%) } \\
\cline { 2 - 6 } \multicolumn{1}{c}{ Perlakuan } & $\begin{array}{c}\text { Sangat } \\
\text { tidak } \\
\text { Suka }\end{array}$ & $\begin{array}{c}\text { Tidak } \\
\text { Suka }\end{array}$ & Netral & Suka & $\begin{array}{c}\text { Sangat } \\
\text { Suka }\end{array}$ \\
\hline A Tanpa Penambahan Tepung Tapioka & 0 & 5 & 45 & 40 & 15 \\
B Penambahan 5\% Tepung Tapioka & 0 & 0 & 45 & 55 & 0 \\
C Penambahan 10\% Tepung Tapioka & 0 & 15 & 50 & 20 & 15 \\
D Penambaha 15\% Tepung Tapioka & 0 & 20 & 55 & 10 & 15 \\
\hline
\end{tabular}


Tingkat kesukaan terhadap tekstur

Hasil pengamatan tingkat kesukaan panelis terhadap tekstur pada biskuit ubi Banggai dengan penambahan tepung tapioka diperoleh dari nilai rata-rata berkisar 3,5-3,8 yaitu suka dan sangat suka, dapat dilihat pada tabel 7 . Berdasarkan hasil penilaian tingkat kesukaan, nilai tertinggi terdapat pada perlakuan D (penambahan $15 \%$ tepung tapioka) yaitu 3,8, sedangkan nilai terendah pada perlakuan A (tanpa penambahan tepung tapioka) dan perlakuan B (penambahan 5\% tepung tapioka) dengan nilai 3,5 pada kriteria suka.

Hasil analisis sidik ragam tidak menunjukkan pengaruh nyata dari penambahan tepung tapioka terhadap tingkat kesukaan pada tekstur biskuit ubi Banggai. Efek fungsional pati dalam pembentukan tekstur dapat terdeteksi jika ada perbedaan perbandingan yang signifikan antara amilosa dan amilopektin (Sayangbati, 2012).
Berdasarkan persentase yang menunjukan variasi respons panelis terhadap tekstur biskuit ubi Banggai dapat dilihat pada tabel 8. Hasil analisis varians dari variabel panelis menunjukkan pengaruh panelis tidak berbeda dengan nilai rata-rata tingkat kesukaan panelis terhadap tekstur biskuit. Nilai kriteria suka dan sangat suka bervariasi berkisar antara 55-65\% dari total panelis. Nilai tertinggi diperoleh pada perlakuan A (tanpa penambahan tepung tapioka), C (penambahan $10 \%$ tepung tapioka) dan perlakuan D (penambahan 15\% tepung tapioka) dengan persentase tertinggi pada kriteria suka dan sangat suka sebanyak $65 \%$ panelis.

Secara keseluruhan, tingkat kesukaan terhadap rasa, aroma, warna, dan tekstur biskuit ubi Banggai tanpa penambahan tepung tapioka mempunyai nilai rata-rata tertinggi yaitu 3,68 pada kriteria suka (tabel 9).

Tabel 7. Nilai rata-rata tingkat kesukaan panelis terhadap tekstur biskuit

\begin{tabular}{lcl}
\hline Perlakuan & Rata-rata & \\
\hline A Tanpa Penambahan Tepung Tapioka & 3,5 & Suka \\
B Penambahan 5\% Tepung Tapioka & 3,5 & Suka \\
C Penambahan 10\% Tepung Tapioka & 3,7 & Suka \\
D Penambahan 15\% Tepung Tapioka & 3,8 & Suka \\
\hline
\end{tabular}

Tabel 8. Persentase tingkat kesukaan panelis terhadap tekstur

\begin{tabular}{lcccccc}
\hline & \multicolumn{5}{c}{ Persentase (\%) } \\
\cline { 2 - 6 } Perlakuan & $\begin{array}{c}\text { Sangat } \\
\text { Tidak } \\
\text { Suka }\end{array}$ & $\begin{array}{c}\text { Tidak } \\
\text { Suka }\end{array}$ & Netral & Suka & $\begin{array}{c}\text { Sangat } \\
\text { Suka }\end{array}$ \\
\hline A Tanpa Penambahan Tepung Tapioka & - & 20 & 20 & 55 & 5 \\
B Penambahan 5\% Tepung Tapioka & - & 15 & 30 & 45 & 10 \\
C Penambahan 10 \% Tepung Tapioka & - & 10 & 25 & 60 & 5 \\
A Tanpa Penambahan Tepung Tapioka & - & 5 & 30 & 50 & 15 \\
\hline
\end{tabular}


Tabel 9. Tingkat kesukaan secara keseluruhan terhadap biskuit

\begin{tabular}{lccccc}
\hline \multicolumn{1}{c}{ Perlakuan } & Rasa & Aroma & Warna & Tekstur & $\begin{array}{c}\text { Rata- } \\
\text { rata }\end{array}$ \\
\hline A. Tanpa Penambahan Tepung Tapioka & 3,7 & 3,9 & 3,6 & 3,5 & 3,68 \\
B. Penambahan 5\% Tepung Tapioka & 3,4 & 3,8 & 3,6 & 3,5 & 3,58 \\
C. Penambahan 10\% Tepung Tapioka & 3,6 & 3,6 & 3,4 & 3,7 & 3,58 \\
D. Penambahan15\% TepungTapioka & 3,5 & 3,8 & 3,2 & 3,8 & 3,58 \\
\hline
\end{tabular}

\section{Komposisi Kimia Biskuit Kadar Air}

Rata-rata kadar air dari biskuit berbahan baku tepung ubi Banggai dengan penambahan tepung tapioka berkisar antara 2,86\% - 3,98\% (gambar 1).

Kadar air tertinggi terdapat pada perlakuan A (tanpa penambahan tepung tapioka) yaitu 3,98\%, diikuti perlakuan B (penambahan 5\% tepung tapioka) 3,72\%, perlakuan C (penambahan 10\% tepung tapioka) 3,54\%, dan perlakuan D (penambahan 15\% tepung tapioka) dengan kadar 2,86\%. Tingginya kadar air pada perlakuan A dipengaruhi dari proporsi bahan baku tepung ubi Banggai 100\% sehingga menyebabkan peningkatan kadar air pada biskuit.

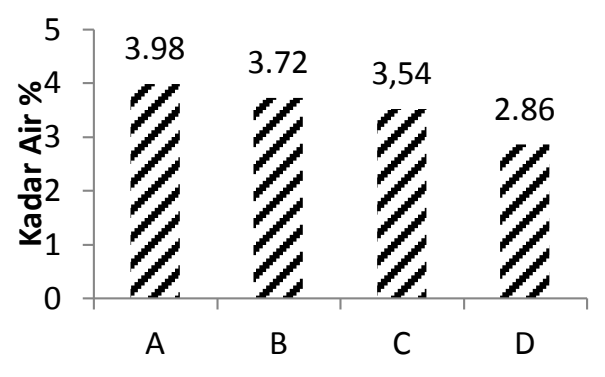

Gambar 1. Kadar air biskuit ubi Banggai, A. tanpa penambahan tepung tapioka; B. penambahan 5\% tepung tapioka; C. penambahan $10 \%$ tepung tapioka; D. penambahan $15 \%$ tepung tapioka.

Berdasarkan syarat mutu biskuit menurut Standar Nasional Indonesia (012973-1992) kadar air pada biskuit maksimum 5\% dengan demikian biskuit tepung ubi Banggai pada perlakuan ini memenuhi Standard Nasional Indonesia.

\section{Kadar Protein}

Protein merupakan zat makanan yang penting bagi tubuh manusia, karena berfungsi sebagai bahan bakar dalam tubuh dan juga sebagai bahan pembangun dan pengatur (Winarno, 2004). Hasil analisis kadar air pada biskuit ditunjukkan pada gambar 2 .

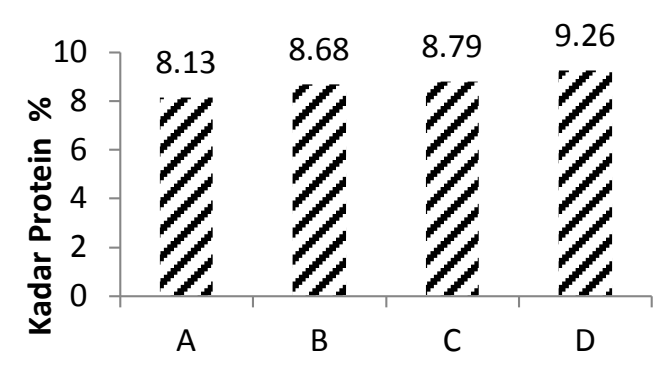

Gambar 2. Kadar protein biskuit ubi Banggai, A. tanpa penambahan tepung tapioka; B. penambahan 5\% tepung tapioka; C. penambahan $10 \%$ tepung tapioka; D. penambahan $15 \%$ tepung tapioka.

Rata-rata kadar protein dari biskuit tepung ubi Banggai dengan penambahan tepung tapioka berkisar antara 8,13\% 9,26\%. Dari hasil analisis kadar protein tertinggi pada perlakuan D (penambahan 15\% tepung tapioka) dengan kadar 9,26\%, perlakuan C (penambahan $10 \%$ tepung tapioka) dengan kadar 8,79\%, kemudian perlakuan B (penambahan 5\% tepung tapioka) dengan kadar 8,68\%, dan kadar protein terendah pada perlakuan A (tanpa penambahan tepung tapioka). Tingginya kadar protein pada perlakuan D dipengaruhi oleh kandungan protein dari 
tepung tapioka dengan proporsi lebih banyak dari perlakuan lain.

Berdasarkan syarat mutu biskuit menurut Standar Nasional Indonesia (012973-1992) kadar protein pada biskuit minimum 9\% dengan demikian biskuit tepung ubi Banggai pada perlakuan ini memenuhi Standard Nasional Indonesia.

\section{Kadar Lemak}

Lemak dibutuhkan dalam pembuatan biskuit, lemak memiliki efek shortening pada makanan yang dipanggang seperti biskuit, kue kering dan roti sehingga menjadi lebih rendah (Ghaman dan Sherington, 1992). Kadar lemak juga dapat dapat mempengaruhi mutu, umur simpan dan karakteristik pangan yang dihasilkan. Hasil analisis kadar lemak pada biskuit ditunjukkan pada gambar 3 .

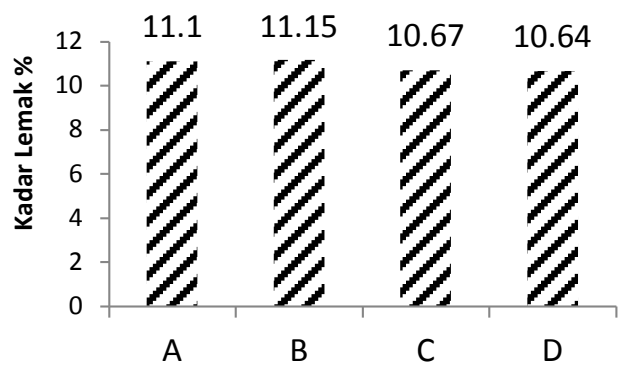

Gambar 3. Kadar lemak biskuit ubi Banggai, A. tanpa penambahan tepung tapioka; B. penambahan 5\% tepung tapioka; C. penambahan $10 \%$ tepung tapioka; D. penambahan $15 \%$ tepung tapioka.

Rata-rata kadar lemak dari biskuit berbahan baku tepung ubi Banggai dengan penambahan tepung tapioka berkisar antara 10,64\% - 11,15\%. Dari hasil analisis kadar lemak tertinggi pada perlakuan B (penambahan 5\% tepung tapioka) dengan kadar 11,15\%, kemudian perlakuan A (tanpa penambahan tepung tapioka) dengan kadar 11,1\%, perlakuan C (penambahan $10 \%$ tepung tapioka) dengan kadar 10,67\%, dan kadar lemak terendah pada perlakuan D (15\% tepung tapioka) berkisar 10,64. Tepung tapioka memiliki kadar lemak sebesar 0,2\%, sehingga semakin sedikit penambahan tepung tapioka maka kandungan lemak semakin tinggi.

Berdasarkan syarat mutu biskuit menurut Standard Nasional Indonesia (012973-1992) kadar lemak pada biskuit minimum 9,5\% dengan demikian biskuit tepung ubi Banggai pada perlakuan ini memenuhi Standard Nasional Indonesia.

\section{Kadar Abu}

Menurut Sudarmadji (2003), abu adalah bahan zat organik sisa hasil pembakaran suatu bahan organik. Kadar abu berhubungan dengan mineral yang terkandung dalam suatu bahan. Tingginya kadar abu pada suatu bahan pangan yang dihasilkan menunjukkan tingginya kandungan mineral bahan tersebut. Hasil analisis kadar abu pada biskuit ditunjukkan pada gambar 4 .

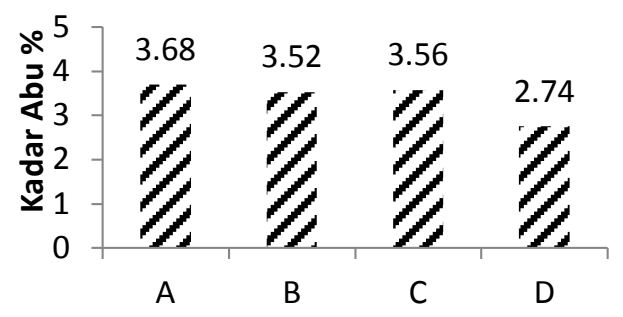

Gambar 4. Kadar abu biskuit ubi Banggai, A. tanpa penambahan tepung tapioka; B. penambahan 5\% tepung tapioka; C. penambahan $10 \%$ tepung tapioka; D. penambahan $15 \%$ tepung tapioka.

Rata-rata kadar abu biskuit berbahan baku tepung ubi Banggai dengan penambahan tepung tapioka berkisar antara 2,74\% - 3,68\%. Dari hasil analisis kadar tertinggi pada perlakuan A (npa penambahan tepung tapioka) dengan 
kadar 3,68\%, kemudian perlakuan C (penambahan $10 \%$ tepung tapioka) dengan kadar 3,56\%, perlakuan B (penambahan $5 \%$ tepung tapioka) dengan kadar 3,52, dan kadar abu terendah pada perlakuan D (penambahan 15\% tepung tapioka) dengan kadar 2,74\%.

Berdasarkan syarat mutu biskuit menurut Standar Nasional Indonesia (012973-1992) kadar abu pada biskuit maksimum 1,6\% dengan demikian biskuit tepung ubi Banggai dengan penambahan tepung tapioka pada perlakuan ini belum memenuhi Standard Nasional Indonesia.

\section{Kadar Karbohidrat}

Analisis kadar karbohidrat dilakukan untuk mengetahui kadar karbohidrat pada biskuit ubi Banggai dan tepung tapioka dari setiap perlakuan. Kadar karbohidrat merupakan sumber energi utama pada manusia. Hasil analisi kadar karbohidrat pada biskuit ditunjukkan pada gambar 5.

Rata-rata kadar karbohidrat dari biskuit berbahan baku tepung ubi Banggai berkisar antara 71,86\%-73,71\%. Dari hasil analisis kadar karbohidrat tertinggi pada perlakuan D (penambahan 15\% tepung tapioka) dengan kadar 73,71\%, kemudian perlakuan C (penambahan 10\% tepung tapioka) dengan kadar 72,68\%, kemudian perlakuan A (tanpa penambahan tepung tapioka) dengan kadar 72,55\%, dan kadar karbohidrat terendah pada perlakuan B (penambahan 5\% tepung tapioka) dengan kadar 71,86\%. Kadar karbohidrat yang dihasilkan tidak berbeda jauh dari setiap perlakuan, tingginya kadar karbohidrat pada perlakuan $\mathrm{D}$ diperoleh dari bahan baku tepung ubi Banggai 31,3\% dan tepung tapioka 88,2\% sehingga menyebabkan peningkatan kadar karbohidrat pada biskuit.

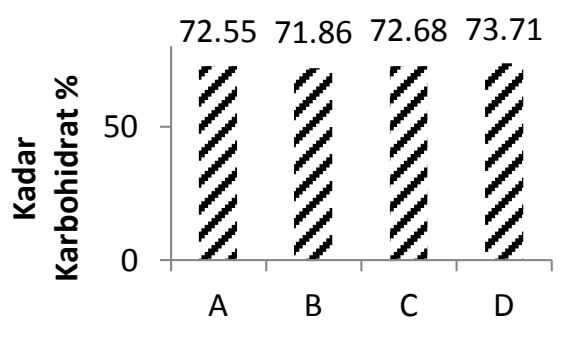

Gambar 5. Kadar karbohidrat biskuit ubi Banggai, A. tanpa penambahan tepung tapioka ; B. penambahan 5\% tepung tapioka; C. penambahan $10 \%$ tepung tapioka; D. penambahan $15 \%$ tepung tapioka.

Berdasarkan syarat mutu biskuit menurut Standard Nasional Indonesia (012973-1992) kadar karbohidrat pada biskuit minimum 70\% dengan demikian biskuit tepung ubi Banggai pada perlakuan ini memenuhi standard Nasional Indonesia

\section{Kadar Serat Kasar}

Analisis serat kasar dilakukan untuk mengetahui kandungan serat kasar pada biskuit ubi Banggai yang didapatkan dari setiap perlakuan. Serat kasar merupakan residu dari bahan makanan atau pertanian yang terdiri dari selulosa dan sedikit lignin dan pentose (Apriyanto, 1989). Hasil analisis kadar serat kasar pada biskuit ditunjukkan pada gambar 6 .

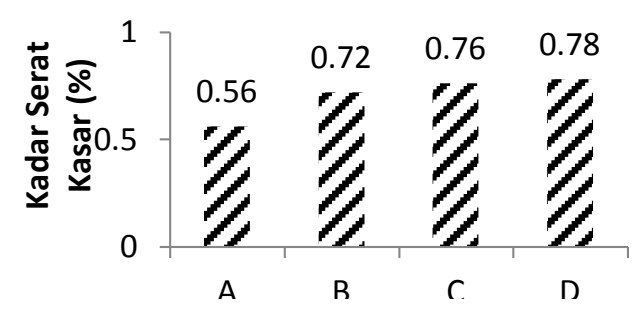

Gambar 6. Kadar serat kasar biskuit ubi Banggai, A.tanpa penambahan tepung tapioka; B. penambahan 5\% tepung tapioka; C. penambahan $10 \%$ tepung tapioka; D. penambahan $15 \%$ tepung tapioka. 
Rata-rata kadar serat kasar dari biskuit tepung ubi banggai dengan penambahan tepung tapioka berkisar antara 0,56\%-0,78\%. Dari hasil analisis tertinggi pada perlakuan $\mathrm{D}$ (penambahan $15 \%$ tepung tapioka) dengan kadar 0,78\%, perlakuan $\mathrm{C}$ (penambahan $10 \%$ tepung tapioka) dengan kadar 0,76\%, perlakuan B (penambahan 5\% tepung tapioka) dengan kadar 0,72\%, dan kadar serat kasar terendah pada perlakuan A(tanpa penambahan tepung tapioka dengan kadar 0,56\%. Tingginya serat kasar pada perlakuan D disebabkan karena kandungan protein pada perlakuan D lebih banyak dibandingkan dengan perlakuan lainnya, sehingga menjadi sulit dalam penyaringan.

Berdasarkan syarat mutu biskuit menurut Standart Nasional Indonesia (012973-1992) serat kasar pada biskuit maksimum 0,5\% dengan demikian biskuit tepung ubi Banggai pada perlakuan ini memenuhi Standard Nasional Indonesia.

\section{Nilai Kalori}

Nilai kalori dihitung untuk mengetahui jumlah kalori pada biskuit ubi Banggai yang didapatkan dari setiap perlakuan. Nilai kalori pada biskuit ditunjukkan pada gambar 7 .

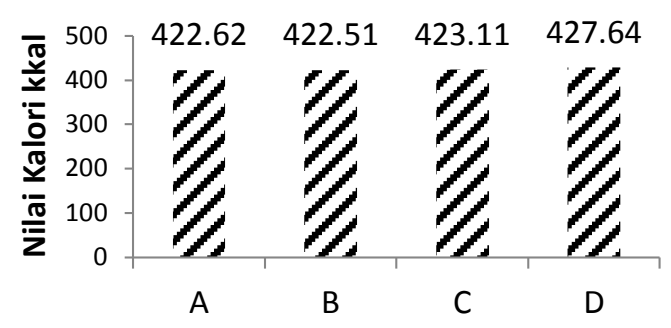

Gambar 7. Nilai kalori biskuit ubi Banggai, A. tanpa penambahan tepung tapioka; B. penambahan $5 \%$ tepung tapioka; C. penambahan $10 \%$ tepung tapioka; D. Penambahan 15\% tepung tapioka
Rata-rata nilai kalori pada biskuit berbahan baku tepung ubi Banggai dengan penambahan tepung tapioka berkisar antara 422,51 - 427,64 kkal. Dari hasil analisis nilai kalori tertinggi pada perlakuan D (penambahan 15\% tepung tapioka) dengan kadar 427,64 kkal, kemudian perlakuan C (penambahan 10\% tepung tapioka) dengan kadar 423,11 kkal, perlakuan A (tanpa penambahan tepung tapioka) dengan kadar 422,62 kkal, nilai kalori terendah pada perlakuan B (penambahan 5\% tepung tapioka) dengan kadar 422,51 kkal

Berdasarkan syarat mutu biskuit menurut Standart Nasional Indonesia (012973-1992) nilai kalori pada biskuit minimum 400 kkal dengan demikian biskuit tepung ubi Banggai pada perlakuan ini memenuhi Standard Nasional Indonesia.

\section{Kekerasan Biskuit}

Nilai kekerasan biskuit berkisar antara 1,83 sampai $1,93 \mathrm{~mm} / \mathrm{g} /$ det dapat dilihat pada gambar 8. Biskuit dengan perlakuan A (tanpa penambahan tepung tapioka) memiliki nilai rata-rata tertinggi yaitu $1,93 \mathrm{~mm} / \mathrm{g} /$ detik. Hal ini menunjukkan bahwa perlakuan A memiliki tekstur yang kurang keras dibandingkan dengan perlakuan D yaitu (penambahan 15\% tepung tapioka) memiliki nilai rata-rata terendah yaitu $1,83 \mathrm{~mm} / \mathrm{g} / \mathrm{det}$. sesuai dengan prinsip penetrometer semakin kecil nilai yang diperoleh, maka tingkat kekerasan yangdiperoleh semakin keras diperoleh, maka tingkat kekerasan yang diperoleh semakin keras. 


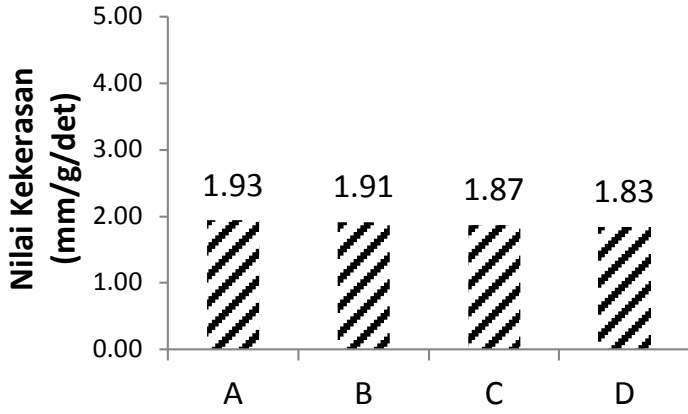

Gambar 8. Kekerasan biskuit ubi Banggai: A.tanpa penambahan tepung tapioka; B. penambahan 5\% tepung tapioka; C. penambahan $10 \%$ tepung tapioka; D. Penambahan $15 \%$ tepung tapioka.

\section{KESIMPULAN}

Berdasarkan uji sensoris tingkat kesukaan terhadap rasa, aroma, warna, dan tekstur, dapat disimpulkan bahwa tepung tapioka tidak perlu ditambahkan dalam pembuatan biskuit ubi Banggai. Secara keseluruhan nilai tingkat kesukaan yang diberikan oleh panelis pada biskuit ubi Banggai tanpa penambahan tepung tapioka adalah 3,68 yaitu pada kriteria suka sebagai nilai tertinggi. Biskuit ubi Banggai ini memiliki kekerasan 1,93 $\mathrm{mm} / \mathrm{g} /$ det. dan nilai kalori 422,62 kkal, dengan komposisi kadar air 3,98\%, protein $8,13 \%$, lemak $11,10 \%$, abu 3,68\%, karbohidrat 72,55\%, dan serat kasar 0,5\%.

\section{DAFTAR PUSTAKA}

Apriyantono, $1986 . \quad$ Petunjuk Laboratorium Analisis Pangan. Departemen Pendidikan dan Kebudayaan. Direktorat Jendral Pendidikan Tinggi Pusat Antar Universitas Pangan dan Gizi. IPB, Bogor.

Baedhowie M dan S. Pranggonawati. 1983. Petunjuk Praktek Mutu Hasil Pertanian. Departemen Pendidikan dan Kebudayaan.
Badan Standarisasi Nasional. 1992. Cara Uji Makanan dan Minuman (SNI 01-2891-1992). BSN, Jakarta.

Badan Standarisasi Nasional. 1992. Cara Uji Makanan dan Minuman (SNI 01-2973-1992). BSN, Jakarta.

Cauvin, S. P. 2003. Bread making improving quality. Camridge: Woodhead Publishing Limited; P 26.

Gaman. M 1992. Pengantar Ilmu Pangan, Nutrisi Dan Mikrobiologi. Edisi II. Yogyakarta: Gadjah Mada University Press

Lestari D. W. 2013. Pengaruh Subtitusi Tepung Tapioka Terhadap Tekstur Dan Nilai Organoleptik Dodol Susu. Skripsi. Fakultas Peternakan, Universitas Brawijaya, Malang.

Meilgaard, M., G, V, Civille, dan B. T. Carr 1999. Sensory Evaluation Techniques. CRC. Press. New York.

Rahayu, W. P. 2001. Penuntun Praktikum Penilaian Organoleptik. Jurnal. Jurusan Teknologi Pangan dan Gizi, Fakultas Teknologi Pertanian., Institut Pertanian. Bogor.

Rahardjo, Y., Sumarni dan A. Dalapati.32016. Diversifikasi Olahan Ubi Banggai Menunjang Ketahanan Pangan. Jurnal. Balai Pengkajian Teknologi Pertanian. Sulawesi Tengah.

Ramadhani, C. 2016. Substitusi Tepung Terigu dengan Tepung Ubi Banggai (Dioscorea alata L.) Dalam pembuatan Mie. Skripsi. Program Studi Agroteknologi, Fakultas Pertanian, Universitas Muhammadiyah Luwuk, Sulawesi Tengah.

Rostiawati, Y. 1990. Penggunaan Tepung Ubi Banggai (Dioscorea alata L.) Sebagai Bahan Substitusi Tepung Terigu Bahan Pembuatan “Cookies”. Skripsi. Jurusan Gizi 
Masyarakat Dan Sumber daya

Keluarga, Fakultas Pertanian, Institut Pertanian Bogor.

Sayangbati. 2012. Karakteristik Fisiko kimia Biskuit Berbahan Baku Tepung Pisang Goroho (Musa acuminate, sp). Skripsi. Program Studi ilmu dan Teknologi Pangan, Universitas Sam Ratulangi.

Sudarmadji, S., B. Haryono dan Suhardi. 1997. Prosedur Analisa untuk Bahan Makanan dan Pertanian. Liberty. Yogyakarta.

Wijaya, H. 2010. Kajian Teknis Standar Nasional Indonesia Biskuit SNI 01-2973-1992. Balai Besar Industri Argo, Kementrian Perindustran..

Winarno, F. G. 2004. Kimia Pangan Dan Gizi. PT Gramedia Pustaka Utama. Jakarta.

Yusuf. 2015. Pertumbuhan Dan Hasil Jenis Ubi Banggai (Dioscoreaspp) Pada Berbagai Pupuk Organik. Program Studi Agroteknologi, Fakultas Pertanian, Universitas Tadulako, Palu. 